\title{
ANALISIS FAKTOR PENYEBAB KESULITAN BELAJAR MATEMATIKA DI KELAS IV SEKOLAH DASAR NEGERI 004 BANGKINANG KOTA (MATERI PECAHAN)
}

\author{
Nor Diana Natasya ${ }^{1}$, Yenni Fitra Surya ${ }^{2}$ Rusdial Marta ${ }^{3}$ \\ 1,2,3 Universitas Pahlawan Tuanku Tambusai, Jl. Tuanku Tambusai No 23 Bangkinang \\ Email penulis pertama: nordiananatasya@yahoo.com
}

\begin{abstract}
Abstrak
Kesulitan belajar adalah ketidakmampuan siswa dalam menguasai fakta, konsep, prinsip dan keterampilan. Penelitian ini bertujuan untuk mengetahui faktor penyebab kesulitan belajar yang dialami oleh siswa kelas IV SD Negeri 004 Bangkinang Kota dalam mempelajari matematika. Dalam penelitian ini teknik sampling yang digunakan adalah sampling jenuh yaitu seluruh siswa kelas IV yang berjumlah 14 orang menjadi subjek dalam penelitian ini. Siswa kelas IV terpilih sebagai subjek berdasarkan hasil observasi peneliti selama masa PPL (Program Praktek Lapangan). Kemudian data diperkuat dengan pengakuan guru mata pelajaran matematika tentang adanya kesulitan belajar matematika di kelas IV tahun ajaran 2018/2019. Teknik yang digunakan untuk mengumpulkan data adalah observasi, wawancara, kuesioner, catatan lapangan, dokumentasi dan checklist. Kuesioner siswa digunakan untuk mengetahui faktor kesulitan belajar matematika siswa, sedangkan wawancara guru, kuesioner orang tua dan catatan lapangan untuk mengakuratkan hasil kuesioner siswa. Dokumentasi dan checklist berfungsi sebagai penunjang dalam penelitian ini. Hasil penelitian ini menunjukkan bahwa faktor penyebab kesulitan belajar matematika siswa kelas IV adalah siswa tidak pernah kecewa saat mendapatkan nilai rendah $(85,7 \%)$, siswa mengalami kesulitan dalam memahami materi menyederhanakan pecahan $(85,7 \%)$ dan guru tidak pernah membawa alat peraga untuk menunjang pemahaman siswa dalam materi menyederhanakan pecahan $(85,7 \%)$. Sehingga diambil kesimpulan bahwa faktor penyebab kesulitan belajar matematika di kelas IV SD Negeri 004 Bangkinang Kota adalah faktor intern dan faktor ekstern. Faktor intern meliputi sikap negative dalam belajar matematika dan motivasi belajar masih rendah. Sedangkan faktor ekstern meliputi kurangnya variasi mengajar guru dan penggunaan media/alat peraga pembelajaran yang belum maksimal.
\end{abstract}

Kata Kunci: Kesulitan Belajar, Matematika, Sekolah

\begin{abstract}
The Learning difficulties are the inability of students to master facts, concepts, principles and skills. This study aims to determine the factors that cause learning difficulties experienced by fourth grade students of Bangkinang City State Elementary School 004 in learning mathematics. In this study the sampling technique used was saturated sampling, which is that all IV grade students totaling 14 people were the subjects in this study. The Fourth grade students are selected as subjects based on the observations of researchers during the PPL (Field Practice Program) period. Then the data is strengthened by the recognition of mathematics teachers about the difficulty of learning mathematics in the fourth grade of the 2018/2019 academic year. The technique used to collect data is observation, interviews, questionnaires, field notes, documentation and checklists. Student questionnaires were used to find out the factors of difficulty learning mathematics students, while teacher interviews, parent questionnaires and field notes to validate the results of student questionnaires. The documentation and checklist serve as support in this study. The results of this study indicate that the factors causing difficulties in learning mathematics in grade IV students are never disappointed when they get a low score (85.7\%), students have difficulty understanding the material simplifying fractions $(85.7 \%)$ and the teacher never carries teaching aids to support students' understanding of the material simplifies fractions (85.7\%). So it was concluded that the factors causing difficulties in learning mathematics in class IV of 0014 Bangkinang City Public Elementary School were internal factors and external factors. Internal factors include negative attitudes in learning mathematics and learning motivation is still low. While external factors include the lack of teacher teaching variations and the use of media / teaching aids that have not been maximized.
\end{abstract}

Keywords: Learning Difficulties, Mathematics, Schools 


\section{LATAR BELAKANG}

Matematika mempunyai peran penting dalam berbagai disiplin ilmu dalam mengembangkan daya pikir manusia, dengan mempelajari matematika siswa lebih kritis dalam memahami suatu permasalahan dalam kehidupan sehari-hari. Oleh sebab itu, pelajaran matematika perlu diberikan kepada semua siswa mulai dari sekolah dasar sampai ke perguruan tinggi. Demikian pula, tujuan yang diharapkan dalam pembelajaran matematika oleh National Council of Teachers of Mathematics (NCTM). NCTM menetapkan lima standar kemampuan matematis yang harus dimiliki oleh siswa, yaitu kemampuan pemecahan masalah (problem solving), kemampuan komunikasi (communication), kemampuan koneksi (connection), kemampuan penalaran (reasoning) dan kemampuan representasi (representation).

Matematika memiliki tujuan yang sangat penting bagi siswa di sekolah (Hidayat, 2017: 1). Hal ini menyebabkan siswa harus memahami pelajaran matemetika karena matematika membekali siswa untuk mempunyai kemampuan berpikir logis, analitis, sistematis, kritis dan kreatif serta kemampuan bekerja sama. Oleh sebab itu, pelajaran matematika perlu diberikan kepada semua siswa dimulai dari sekolah dasar (Astuti, 2016: 12).

Setiap anak memiliki karakter yang berbeda, begitu juga dalam hal kemampuan akademis yang sering disebut intelektual atau kecerdasan. Sebagian anak memiliki kecerdasan yang dibawah rata-rata, rata-rata, bahkan di atas rata-rata, dan hal ini mempengaruhi prestasi anak di sekolah. Ketika anak tidak mampu berprestasi dengan baik dan memuaskan berdasarkan kecerdasan yang dimiliki, maka anak tersebut dikatakan sebagai anak bermasalah dalam belajar atau kesulitan belajar (Surya, 2017).

\section{Kesulitan Belajar Matematika}

Definisi kesulitan belajar pertama kali dikemukakan oleh The United States Office of Education (USOE) pada tahun 1977 yang dikenal dengan Public Law (PL) 94-142 yang hampir identik dengan definisi yang dikemukakan oleh The National Advisory Committee on Handicapped Children pada tahun 1967 dalam Mulyono (2003, p.6) mengungkapkan kesulitan belajar adalah suatu gangguan dalam satu atau lebih dari proses psikologis dasar yang mencakup pemahaman dan penggunaan bahasa atau ujaran tulisan. Gangguan ini dalam bentuk menampakkan diri dalam bentuk kesulitan mendengarkan, berpikir, berbicara, membaca, menulis, mengeja, atau berhitung (Waskitoningtyas 2016: 25).

\section{Belajar}

Belajar adalah suatu proses usaha yang dilakukan seseorang untuk memperoleh perubahan tingkah laku yang baru secara keseluruhan, sebagai hasil pengalamannya sendiri dalam interaksi dengan lingkungannya (Slameto, 2010, p.2). Tujuan belajar adalah suatu deskripsi mengenai tingkah laku yang diharapkan tercapai oleh siswa setelah berlangsungnya proses belajar (Oemar Hamalik, 2014: 73). Perubahan sebagai proses hasil belajar dapat ditunjukkan dalam berbagai bentuk seperti perubahan pengetahuan, pemahaman, sikap, dan tingkah lakunya, keterampilannya, kecakapan dan 
kemampuannya, daya reaksinya, daya penerimaan dan lain-lain aspek yang ada pada individu (Nana Sudjana, 2002: 28) dalam jurnal Hidayat (2017). Cornelius dalam mulyono Abdurrahman (2012) dalam jurnal Ni Nym (2015, p.1) mengemukakan lima alasan perlunya belajar matematika karena matematika merupakan:
a. Sarana berpikir yang jelas dan logis
b. Sarana untuk memecahkan masalah kehidupan sehari-hari
c. Sarana mengenal pola-pola hubungan dan generalisasi pengalaman
d. Sarana untuk mengembangkan kreativitas
e. Sarana untuk meningkatkan kesadaran terhadap perkembangan budaya

\section{Faktor-faktor Penyebab Kesulitan Belajar Matematika}

Kesulitan belajar merupakan kekurangan yang tidak nampak secara lahiriah.

1) Faktor-faktor Internal

a) Faktor psikologis siswa

- sikap

- Motivasi

- Minat

- Bakat

- Konsentrasi

- Inteligensi

- Kebiasaan belajar

- Ulangan

- Kemampuan berprestasi

2) Faktor-faktor Eksternal

a) Faktor fisiologis siswa

- Guru

- Cara mengajar guru

- Alat peraga / media yang digunakan guru

- Kebijakan penilaian guru

- Orang tua

- Cara orang tua mendidik

- Suasana rumah

- ekonomi

Kesulitan belajar siswa terhadap mata pelajaran matematika seperti jika diperintah oleh guru, siswa tidak mempelajari materi terlebih dahulu dan pada saat proses pembelajaran matematika berlangsung di belakang ada siswa yang berbicara dengan teman sebangkunya, tidak mendengarkan apa yang sedang dijelaskan oleh gurunya di depan kelas, tidak mencatat materi yang disampaikan oleh guru dengan baik dan jika diberi tugas selalu melihat pekerjaan temannya. Ketika guru memberikan tugas untuk dikerjakan masih terlihat siswa yang kurang bersungguh-sungguh untuk mengerjakan soal latihan dan tidak mau berusaha sendiri dalam menyelesaikan tugas, terdapat pula siswa yang tidak serius dalam belajar, karena siswa tersebut bertukar-tukar tempat duduk ketika 
proses pembelajaran berlangsung tanpa sepengetahuan gurunya, ketika guru meminta siswa maju kedepan kelas untuk menyelesaikan soal yang telah diberikan hanya beberapa siswa yang aktif dan berani tampil.

\section{METODE}

Subjek dalam penelitian ini adalah siswa kelas IV SD Negeri 004 Bangkinang Kota kecamatan bangkinang kota kabupaten Kampar provinsi Riau. Jenis penelitian ini adalah Penelitian Kualitatif. Penelitian ini menyelidiki siswa - siswa yang mengalami kesulitan belajar matematika dan peneliti mengumpulkan informasi secara lengkap dengan berbagai prosedur pengumpulan data seperti observasi, wawancara, dokumentasi, dan kuesioner. Teknik pengambilan sampel dalam penelitian ini dilakukan dengan teknik Non-Probability Sampling yaitu Sampling Jenuh. Hal ini sesuai dengan pendapat Sugiyono (2011:126) Sampling Jenuh adalah teknik penentuan sampel bila semua anggota populasi yang digunakan sebagai sampel.

Adapun instrument pengumpul data yang digunakan dalam penelitian ini sebagai berikut:

1. Observasi

Pada penelitian ini observasi dilakukan sewaktu peneliti PPL di SD Negeri 004 Bangkinang Kota, peneliti melakukan observasi mulai dari bulan September 2018 sampai bulan Desember 2018. Peneliti mengobservasi siswa kelas IV di SD Negeri 004 Bangkinang Kota.

2. Wawancara

Wawancara digunakan sebagai teknik pengumpulan data apabila peneliti ingin melakukan studi pendahuluan untuk menemukan permasalahan yang harus diteliti dan juga apabila peneliti ingin mengetahui hal-hal dari responden yang lebih mendalam dan jumlah respondennya sedikit/kecil.

3. Kuesioner

Dalam penelitian ini kuesioner dibuat dengan pernyataan jawaban "ya-tidak" karena peneliti ingin mendapat jawaban yang pasti.

Analisis data dalam penelitian ini adalah :

1. Reduksi data

Miles dan Huberman mengartikan reduksi data sebagai proses pemilihan, pemusatan perhatian pada penyederhanaan, pengabstrakan dan transformasi data "kasar" yang muncul dari catatan-catatan tertulis di lapangan.

2. Penyajian data

Setelah dilakukan reduksi data, langkah selanjutnya adalah penyajian data. Penyajian data dilakukan dengan tujuan memahami informasi yang terjadi di lapangan. Metode yang digunakan dalam penelitian ini adalah analisis deskriptif.

3. Penarikan kesimpulan

Kesimpulan dalam penelitian kualitatif yang diharapkan adalah temuan baru yang belum pernah ada. Temuan ini dapat berupa deskripsi atau gambaran suatu objek yang sebelumnya masih samar, kemudian diteliti agar lebih jelas. Kesimpulan ini digunakan untuk menjawab rumusan masalah yang telah ditentukan. 


\section{HASIL DAN PEMBAHASAN}

Dari enam belas indikator faktor penyebab kesulitan siswa dalam mempelajari matematika terdapat tiga faktor yang paling dominan yaitu: 1) Siswa tidak pernah kecewa saat mendapatkan nilai rendah $85,7 \%$ 2) Siswa mengalami kesulitan dalam memahami materi menyederhanakan pecahan $85,7 \% 3)$ Guru tidak pernah membawa alat peraga untuk menunjang pemahaman siswa dalam materi menyederhanakan pecahan $85,7 \%$.

Setelah data hasil penelitian yang diperoleh melalui kuesioner dan wawancara dideskripsikan di atas, maka dapat dilakukan pembahasan untuk menganalisis faktor-faktor kesulitan siswa dalam mempelajari matematika di SD Negeri 004 Bangkinang Kota tahun ajaran 2018/2019. Dari hasil kuesioner yang telah diberikan kepada siswa, kesulitan belajar yang disebabkan oleh faktorfaktor dari dalam diri siswa sendiri yaitu terlihat 12 orang siswa $(85,71 \%), 5$ orang siswa $(35,71 \%)$ mengatakan siswa tidak senang belajar matematika, 10 orang siswa $(71,42 \%)$ mengatakan siswa tidak senang mengerjakan soal menyederhanakan pecahan, 9 orang siswa $(64,28 \%)$ mengatakan siswa tidak teliti saat mengerjakan soal menyederhanakan pecahan, 12 orang siswa $(85,71 \%)$ mengatakan siswa tidak pernah kecewa saat mendapatkan nilai rendah, 10 orang siswa $(71,42 \%)$ mengatakan siswa tidak tertarik dengan hal-hal yang berhubungan dengan menyederhanakan pecahan.

9 orang siswa $(64,28 \%)$ mengatakan siswa tidak memiliki keinginan untuk mendalami materi menyederhanakan pecahan, 2 orang siswa $(14,28 \%)$ mengatakan siswa tidak bertanya jika belum memahami materi menyederhanakan pecahan, 9 orang siswa $(64,28 \%)$ mengatakan siswa sering tidak konsentrasi dalam memahami materi menyederhanakan pecahan, 7 orang siswa (50\%) mengatakan siswa tidak memperhatikannya saat guru mengajar matematika, 12 orang siswa $(85,71 \%)$ mengatakan siswa mengalami kesulitan dalam memahami materi menyederhanakan pecahan, 4 orang siswa $(28,57 \%)$ mengatakan siswa belajar di rumah, jika ada tugas atau ulangan saja, 7 orang siswa (50\%) mengatakan siswa tidak mempelajari terlebih dahulu materi yang akan diajarkan oleh guru, 0 orang siswa $(0 \%)$ mengatakan siswa tidak belajar untuk mencapai prestasi tinggi dalam pelajaran matematika, 11 orang siswa $(78,57 \%)$ mengatakan siswa tidak peduli bagaimana hasilnya yang utama adalah menyelesaikan tugas matematika.

Sedangkan faktor yang bersumber dari luar diri siswa adalah 12 orang siswa (85,71\%), 5 orang siswa $(35,71 \%)$ mengatakan siswa mengatakan walaupun dalam keadaan sakit, siswa tetap tidak semangat untuk belajar matematika, 0 orang siswa $(0 \%)$ mengatakan siswa selalu merasa mengantuk saat belajar matematika, 5 orang siswa $(35,71 \%)$ mengatakan guru tidak mengupayakan proses pembelajaran matematika berlangsung dalam suasana yang menyenangkan, 0 orang siswa $(0 \%)$ mengatakan guru hanya memperhatikan siswa yang pintar saja saat pembelajaran matematika berlangsung, 11 orang siswa $(78,57 \%)$ mengatakan guru tidak menggunakan media pembelajaran selain buku matematika di kelas, 12 orang siswa $(85,71 \%)$ mengatakan guru tidak pernah membawa alat peraga untuk menunjang pemahaman siswa dalam materi menyederhanakan pecahan, 0 orang siswa $(0 \%)$ mengatakan guru tidak menghargai hasil pekerjaan setiap siswa, 0 orang siswa $(0 \%)$ mengatakan siswa tidak mengikuti remedial di sekolah, jika nilai matematika saya belum tuntas.

0 orang siswa $(0 \%)$ mengatakan ketika mengerjakan tugas matematika di rumah, orang tua 
siswa tidak memberi dorongan untuk semangat belajar, 1 orang siswa $(7,14 \%)$ mengatakan orang tua siswa tidak menanyakan perkembangan belajar anaknya di sekolah, 0 orang siswa ( $0 \%)$ mengatakan orang tua siswa selalu sibuk bekerja, sehingga tidak pernah peduli dengan hasil belajar matematika anaknya, 5 orang siswa $(35,71 \%)$ mengatakan siswa tidak mempunyai ruang khusus belajar, 0 orang siswa $(0 \%)$ mengatakan siswa tidak diawasi oleh orang tua ketika belajar di rumah, 4 orang siswa $(28,57 \%)$ mengatakan di rumah siswa selalu belajar bersama adik atau kakak, 0 orang siswa $(0 \%)$ mengatakan suasana di rumah siswa tidak tenang dan tentram, sehingga siswa tidak nyaman untuk belajar, 0 orang siswa $(0 \%)$ mengatakan orang tua siswa selalu keberatan memenuhi kebutuhan alatalat belajar matematika anaknya, 10 orang siswa $(71,42 \%)$ mengatakan siswa tidak dimasukkan oleh orang tua les diluar jam sekolah.

Berdasarkan hasil wawancara antara peneliti dan guru matematika kelas IV SD Negeri 004 Bangkinang Kota, ibu Syafrida, S. Pd pada hari Senin 13 Mei 2019 yaitu ibu syafrida selaku guru yang telah mengajar selama 18 tahun juga merasa heran pada kelas yang diampuh pada tahun ini, karena siswa siswinya memiliki keterampilan pemahaman yang kurang. Dimana terdapat siswa yang tidak hapal perkalian dan ada yang tidak bisa membaca, walaupun demikian, ibu syafrida sudah berusaha untuk mengusahakan siswa mudah memahami konsep menyerdahanakan pecahan. Ibu syafrida juga sudah mencoba untuk menciptakan suasana menyenangkan sebelum belajar agar tercipta suasana pembelajaran yang kondusif. Beliau juga berusaha untuk menjelaskan kembali materi jika banyak siswa yang tidak mengerti bahkan beliau membuka peluang untuk siswa yang ingin les dengannya atau pun siswa yang ingin les di bimbel yang ada. Dalam memperlakuan siswapun beliau bersikap adil dan tidak membeda-bedakan antara siswa, serta untuk penilaian siswa beliau juga menilai dengan kemampuan dan hasil yang didapatkan siswa.

Menurut saya, kurangnya pemahaman konsep siswa disebabkan diantaranya dimana ibu syafrida tidak menggunakan model atau metode pembelajaran yang bervariasi dalam mengajar, dimana beliau lebih menggunakan metode konvensional. Untuk masalah ini, harusnya ada pelatihan khusus untuk guru-guru untuk mengenal pembelajaran K-13. Banyak guru menganggap K-13 rumit karena mereka tidak paham dengan K-13 tersebut. Padahal banyak sekali metode atau model pembelajaran yang bisa dipakai untuk memvariasikan pembelajaran agar dapat tercapai tujuan pembelajaran yang maksimal. Begitu juga dengan penggunaan media pembelajaran seadanya, padahal banyak sekali media pembelajaran interaktif yang dapat digunakan untuk materi pecahan. Serta kurangnya fasilitas sarana dan prasarana untuk memaksimalkan pembelajaran di sekolah.

\section{KESIMPULAN}

Berdasarkan deskripsi hasil penelitian dan pembahasan yang telah dilakukan tentang "Analisis Faktor Penyebab Kesulitan Belajar Matematika di Kelas IV SD Negeri 004 Bangkinang Kota (Materi Pecahan)" tahun ajaran 2018/2019 maka dapat diambil kesimpulan sebagai berikut:

1. Faktor dari dalam diri siswa (Intern)

Faktor intern yang menyebabkan kesulitan dalam mempelajari matematika siswa kelas IV SD Negeri 004 Bangkinang Kota yaitu indikator sikap (57,1\%), motivasi $(85,7 \%)$, minat $(67,8 \%)$, bakat $(14,2 \%)$, konsentrasi $(57,1)$, inteligensi $(85,7 \%)$, kebiasaan belajar $(28,5 \%)$, ulangan (ingatan) (50\%), kemampuan berprestasi $(39,2 \%)$ dan kesehatan $(17,8 \%)$. 
2. Faktor dari luar siswa (Ekstern)

Faktor yang bersumber dari luar diri siswa ekstern yaitu indikator cara mengajar guru $(17,8 \%)$, alat peraga/media yang digunakan guru $(82,1 \%)$, kebijakan penilaian guru $(0 \%)$, cara orangtua mendidik (3,6\%), suasana rumah (12,8\%) dan ekonomi $(35,7 \%)$.

\section{IMPLIKASI}

Berdasarkan hasil penelitian yang ditemukan faktor-faktor kesulitan belajar matematika di SD Negeri 004 Bangkinang Kota pada materi pecahan kelas IV yaitu faktor intern adalah indikator motivasi $(85,7 \%)$ dan indikator inteligensi $(85,7 \%)$ sedangkan faktor ekstern adalah media atau alat peraga $(82,1 \%)$.

\section{SARAN}

Berdasarkan kesimpulan diatas maka penulis memberi saran sebagai berikut:

1. Bagi Guru

Mengingat pentingnya penguasaan matematika dengan baik guru sebaiknya mengajarkan matematika dengan bervariasi yang sesuai dengan teori belajar matematika disertai penggunaan alat peraga yang dapat meningkatkan motivasi belajar siswa.

\section{Bagi Siswa}

Siswa hendaknya meningkatkan motivasi belajar agar lebih siap sedia dan percaya diri dalam mengerjakan tugas matematika dan mengingat konsentrasi sangat penting dalam pembelajaran matematika maka sebaiknya seorang siswa harus bisa memusatkan perhatian dan focus agar bisa menerima pelajaran matematika dengan baik.

3. Bagi Orang Tua

Hendaknya orang tua senantiasa memperhatikan perkembangan belajar anak khususnya memberi perhatian pada kesulitan belajar matematika yang dialami. Selain itu orang tua hendaknya menumbuhkan motivasi belajar siswa dan memberikan hal positif bahwa matematika adalah pelajaran yang menyenangkan sehingga siswa mempunyai sikap positif pada pelajaran matematika.

4. Bagi Peneliti Lain

Penelitian ini tidaklah sempurna, diharapkan kepada peneliti selanjutnya agar dapat mencari faktor-faktor lain yang dapat menjadi penyebab kesulitan siswa dalam mempelajari matematika. Penulis mohon maaf atas ketidak sempurnaan hasil penelitian ini.

\section{DAFTAR PUSTAKA}

Abdurrahman, M. (2012). Anak Berkesulitan Belajar. Jakarta: PT Rineka Cipta.

Astuti. (2016). Pengaruh Model Pembelajaran Kooperatif Tipe Two Stay Two Stray (Tsts) Terhadap Hasil Belajar Matematika Siswa Kelas VII SMP Negeri 2 Bangkinang Kota. Jurnal Cendekia: Jurnal Pendidikan Matematika, 1(2), hlm. 11-28.

Aunurrahman. (2012). Belajar dan Pembelajaran. Bandung: Alfabeta. 
Bahri, S. (2011). Psikologi Belajar. Bandung: Alfabeta.

Ghufron, M. N. (2015). Kesulitan Belajar Pada Anak Identifikasi Faktor Yang Berperan Jurnal: Elementary, 3(2), hlm. 297-311.

Hidayat, A. (2017). Penggunaan Strategi Mencari Jawaban Untuk Meningkatkan Hasil Belajar Matematika Siswa Kelas V Sdn 030 Pulau Permai Kecamatan Tambang Kabupaten Kampar. Jurnal Cendekia: Jurnal Pendidikan Matematika, 1(1), hlm. 88-99.

Ismail. (2016). Diagnosis Kesulitan Belajar Siswa Dalam Pembelajaran Aktif Di Sekolah. Jurnal Edukasi, 2(1), hlm. 30-43.

Mutadlo, A. (2013). Kesulitan Belajar (Learning Difficult) Dalam Pembelajaran Matematika. Jurnal Edu-Math, 4(1), hlm. 38-45.

Nym, Dkk. (2015). Analisis Kesulitan-Kesulitan Belajar Matematika Siswa Kelas V Dalam Implementasi Kurikulum 2013 Di Sd Piloting Se-Kabupaten Gianyar Tahun Pelajaran 2014/2015 Jurnal Universitas Pendidikan Ganesha: Journal PGSD, 3(1), hlm. 01-11.

Oemar Hamalik. (2014). Proses Belajar Mengajar. Bandung: Bumi Aksara.

Peraturan Menteri Pendidikan dan Kebudayaan Republik Indonesia Nomor 24 Tahun 2016. (N.D.).

Sugiyono (2010). Memahami Penelitian Kualitatif. Bandung: Alfabeta.

Sugiyono (2011). Metode Penelitian Kombinasi (Mixed Methods). Bandung: Alfabeta.

Sugiyono.(2016). Metode Penelitian Kuantitatif Kualitatif Dan R\&D. Bandung: Alfabeta.

Sukardi. (2012). Metodologi Penelitian Pendidikan. Jakarta: Bumi Aksara.

Yeni, E. M. (2015). Kesulitan Belajar Matematika Di Sekolah Dasar Jurnal: JUPENDAS, 2(2), hlm. 01-10.

Yenni, F.S. dkk (2017). Analisis Kesulitan Belajar Mahasiswa PGSD STKIP Pahlawan Tuanku Tambusai Pada Mata Kuliah Konsep Dasar IPS SD Tahun Ajaran 2016/2017 Jurnal: Basicedu, 1(2), hlm. 01-09.

Waskitoningtyas, R. S. (2016). Analisis Kesulitan Belajar Matematika Siswa Kelas V Sekolah Dasar Kota Balikpapan Pada Materi Satuan Waktu Tahun Ajaran 2015/2016 Jurnal: Jurnal IImiah Pendidikan Matematika, 5(1), hlm. 24-32. 